\title{
Ramie (Boehmeria nivea) Plant Nutrient Quality as Feed Forage at Various Cutting Ages
}

\author{
Sari Suryanah', Ana Rochana², lin Susilawati², and Nyimas Popi Indiriani ${ }^{2}$ \\ ${ }^{1}$ Faculty of Agriculture, University of Bandung Raya, Bandung, Indonesia \\ ${ }^{2}$ Faculty of Animal Husbandry, Padjadjaran University, Bandung, Indonesia \\ Corresponding author email: hikmah99@yahoo.co.id
}

\begin{abstract}
This study was aimed to determine the nutrient quality of the ramie plant (Boehmeria nivea) at various cutting ages. The research was conducted in the Margamulya village RT. 01 RW. 13 Cikandang districts, Garut. The design used was Completely Randomized Design with four (4) treatments and five (5) replications, namely; the treatment of 15-days cutting-age, 30-days cutting-age, 45-days cutting-age, and 60-days cuttingage. The results showed that the cutting age had significant effect $(p<0.05)$ on crude protein, crude fiber, and lignin content of ramie forage. The older cutting age had the decreased crude protein content, while increased the crude fiber and lignin content. The best cutting age of ramie plant as forage for optimal nutrients quality was 30 days.
\end{abstract}

Key words : ramie, cutting age, nutrient quality, feed, forage

Abstrak. Penelitian ini bertujuan untuk mengetahui kualitas nutrien tanaman rami (Boehmeria nivea) pada berbagai umur pemotongan. Penelitian dilaksanakan di Desa Margamulya RT. 01 RW. 13 Kecamatan Cikandang Kabupaten Garut. Rancangan yang digunakan adalah Rancangan Acak Lengkap dengan 4 (empat) perlakuan dan 5 (lima) kali ulangan, yaitu perlakuan umur pemotongan 15 hari, umur pemotongan 30 hari, umur pemotongan 45 hari dan umur pemotongan 60 hari. Hasil penelitian menunjukkan bahwa umur pemotongan berpengaruh nyata $(p<0,05)$ terhadap kandungan protein kasar, serat kasar, dan lignin hijauan rami. Semakin tua umur pemotongan maka kandungan protein kasar semakin menurun, sedangkan kandungan serat kasar dan lignin semakin meningkat. Umur pemotongan terbaik bagi tanaman rami sebagai hijauan pakan dengan kualitas nutrien optimal adalah pada umur 30 hari.

Kata kunci : rami, umur pemotongan, kualitas nutrien, pakan, hijauan

\section{Introduction}

One of the goals of farming business was generating the high production, for both in benefit addition as well as in order to meet the population needs of animal protein. The best way to reach the goal was improving the animal feed. The better the quality of feed, the better the productivity of livestock.

Forage was the feed source of fiber that can be digested by ruminants because of the rumen microorganisms role. In order to optimalize the livestock production, the provision of feed quality should always be considered. At the time, farmers in Indonesian, especially ranchers people used improvised forage such as grass field, so the quality was low and this will affect the livestock production. In addition, special cultivation of feed forage was only done by a few of farmers, because of land and knowledge limited. Therefore, it was required to provide the alternative forage planting that was easy treatment, fast grow and high nutrient content, one of which was the ramie plant.

Initially the ramie plant was widely cultivated in Indonesia as a fiber producer for the textile industry, but after long time these plants was began to be abandoned by the people for the fiber produced. According to Purwati (2010), several obstacles in the development of ramie in Indonesia were varieties and seeds used were not yet pure, location was far from transportation facilities, limited decorticator equipment, not suitable appropriate institutional, obscurity market and price, benefits gained after the third year, and the machine used by the textile factory was not appropriate because it was a cotton processing machine (short fiber). Farmers prefered to plant 
the land with vegetables or other crops because it was more profitable than ramie, even though this plant had the potential to be developed as a forage crop. According to FAO (2005), ramie plants per hectare can produce up to 300 tons of fresh forage / year, equivalent to 42 tons of dry matter. Ramie plant meets all the main elements of macro nutrients required or livestock and contained $16.35 \%$ crude protein, $6.36 \%$ crude lipid, $13.61 \%$ crude fiber and $20.50 \%$ ash (Despal et al., 2011). According to De Toledo et al. (2008), the crude protein content of ramie leaves ranged from $19 \%$ while alfalfa was $20 \%$.

The cutting age was the something that must be considered in the cultivation of feed crops because it could affect productivity. Information about harvesting age was very important in managing the feed crop production and quality to produce the optimal nutrients. Cutting ramie stem for the fiber could be made every 60 days, while cutting for the feed could be done more often. The best harvesting for forage plants was before flowering or in the late vegetative to early bloom phase.

Ramie plant especially Pujon 10 clones started flowering at 20-30 days after harvested for fiber at 60 days of age (Balittas, 2014). Rami cultivated for textile fibers should generate strong trunk fiber contained high cellulose and lignin. As for animal feed, the lignin was a limiting factor in digestibility of feed. The higher the lignin, the lower the digestibility. Therefore, the appropriate age for harvesting of ramie plant as a source of forage should be investigated to obtain the optimal forage quality.

\section{Materials and Methods}

The research material was ramie plant (Boehmeria nivea) Pujon 10 clones that had been planted for four years in an area of 410 $\mathrm{m}^{2}$. The research location was a plateau area with altitude of about 1,310 $\mathrm{m}$ above sea level, the temperature was $19^{\circ}-26^{\circ} \mathrm{C}$ and average rainfall of 2,500 $\mathrm{mm}$ per year (Margamulya village, Cikajang district, 2005).

Experimental plots were made with the size of $2 \times 2 \mathrm{~m}$. Ramie planted land was weeded and cleaned from weeds which were scattered around the plant. Initial cutting (trimming) was done and purposed for uniform plant growth. The cutting height was $\pm 6 \mathrm{~cm}$ above the soil surface. Each plot was marked according to treatment of cutting age. Cutting dates were previously noted and scheduled for further cuts.

The ramie nutrients were crude protein and crude fiber analyzed by proximate analysis method (AOAC, 2005), and lignin analyzed by the method of Goering and Van Soest (1970). Research was conducted by experimental method. The design used was Completely Randomized Design (CRD) with 4 treatments of cutting age and 5 replications. The treatment in this study were $\mathrm{P} 1$ = cutting age of 15 days; $\mathrm{P} 2=$ cutting age of 30 days; $\mathrm{P} 3=$ cutting age of 45 days; and P4 = cutting age of 60 days. Duncan's multiple range test was conducted to see the difference between treatments. The data were also analyzed using regression analysis procedure to determine the pattern of decrease and increase in nutrients from the ramie plant. The regression equation is selected based on the value of the highest coefficient of determination $\left(R^{2}\right)$ and the lowest standard error (SE).

\section{Results and Discussions}

\section{Crude Protein Content of Ramie Plant at Various Cutting Ages}

Crude protein is an essential nutrient needed in ruminant feed, beside it is required by ruminants for growing, the protein can also build and maintain the cells and tissues of the body. The average of crude protein, crude fiber and lignin content of ramie plant at various cutting ages can be seen in Table 1 . 
Table 1. Average of Crude Protein, Crude Fiber and Lignin Content of Ramie Plant at Various Cutting Ages

\begin{tabular}{cccc}
\hline Treatments & Crude Protein (\%) & Crude Fiber (\%) & Lignin (\%) \\
\hline P1 & $31.82 \pm 0.84^{\mathrm{a}}$ & $23.68 \pm 0.65^{\mathrm{a}}$ & $2.70 \pm 0.25^{\mathrm{a}}$ \\
P2 & $29.20 \pm 0.75^{\mathrm{b}}$ & $29.44 \pm 0.51^{\mathrm{b}}$ & $4.20 \pm 0.11^{\mathrm{b}}$ \\
P3 & $24.58 \pm 0.57^{\mathrm{c}}$ & $39.57 \pm 0.30^{\mathrm{c}}$ & $7.27 \pm 0.39^{\mathrm{c}}$ \\
P4 & $20.65 \pm 0.31^{\mathrm{d}}$ & $44.83 \pm 0.59^{\mathrm{d}}$ & $9.88 \pm 0.49^{\mathrm{d}}$ \\
\hline
\end{tabular}

Notes: $\mathrm{P} 1$ = cutting age of 15 days; $\mathrm{P} 2$ = cutting age of 30 days; $\mathrm{P} 3$ = cutting age of 45 days; $\mathrm{P} 4$ = cutting age of 60 days

The data in Table 1 show that the increased the cutting age, the percentage of crude protein content decreased. Results of variance analysis showed that the age of cutting significantly affected on crude protein content of the ramie plant $(p<0.05)$. Further test with Duncan's multiple range test was conducted to determine the effect of differences between treatments.

The data in Table 1 indicate that the crude protein content of each treatment show significant differences. Plant at a young age has a higher protein content than plant in old age. Cutting age of 15 days containing the highest crude protein content at $31.82 \%$, and the lowest is in the cutting age of 60 days at $20.65 \%$. This is because in the older the plant, the plant cell wall formation which are largely composed from cellulose and hemicellulose increased compared to the formation of the cell contents, so that the fiber content is increasing while the value of nutrients including protein is decreasing. This is in accordance with the opinion of Susetyo et al. (1994), that the plant at a young age has better quality because has lower crude fiber and higher protein content. Low levels of protein in older plants can also be caused by the percentage of stems is higher than leaves.

Savitri et al. (2014) research results, showed that the crude protein content of Gliricidia (Gliricidia sepium) decreased with increasing age of cutting. The older the age of the plant, the stems and flower production increased, but decreased leaf production, and this affects the protein content of the plant. Wahyuni and Kamaliyah (2012) research results, also showed that the crude protein content of tropical alfalfa (Medicago sativa) declines as cutting age increases. This is because the cell wall or crude fiber dominates the old plant, while the young plants have many leaves that contain high chlorophyll, which is one source of protein.

The decreasing rate in crude protein content of ramie plant at various cutting ages can be seen in Figure 1. It appears a pattern of declining crude protein content of ramie plant formed a cubic curve. The regression equation formed is $Y=29.752+0,354 X-0,016 X^{2}+$ $0,0001 X^{3}$, the correlation coefficient $r 0.991$ indicates that the relationship between cutting age and reduction in crude protein content is very strong (Sarwono, 2006).

\section{Crude Fiber Content of Ramie Plant at Various Cutting Ages}

Forage fiber fraction varies depending on the growth, chemical composition and structure of these plants. The data in Table 1 show that the crude fiber content of the ramie plant increases with increasing of cutting age. The lowest average of the crude fiber content obtained in treatment $\mathrm{P} 1$ or 15 days cutting age at $23.68 \%$, while the highest average of the crude fiber content obtained in the treatment of cutting age $\mathrm{P} 4$ or 60 days at $44.83 \%$.

Cellulose and hemicellulose are the main components of cell walls in a large quantities in the plants. Ramie plant itself has been cultivated as a fiber producer. Cellulose and lignin is one of the criteria that demonstrate the 
power of fiber. Therefore the 60 days age is enough age in which the fibers produced is high. Results of variance analysis showed that the cutting age significantly affected on crude fiber content of the ramie plant $(p<0.05)$. Further test with Duncan's multiple range test was conducted to determine the effect of differences between treatments.

The data in Table 1 indicate that the crude fiber content of each treatment show significant differences. In the older age of the plant the cell wall formation process still continue to rise. The cell walls of plants composed of cellulose, hemicellulose, and lignin which are linked each other and as a component of crude fiber. In addition, the increased production of crude fiber was also caused by the process of lignification are increasing as the cutting age increase. Hidayat (1995) states that the increasing age of the plant due to the cellulose, hemicellulose and lignin increased. Increased lignin and cellulose causes the rod will be even greater, and growing cambium stem becomes hard and large.

The study results of Djuned et al. (2005), showed that the content of the fiber fraction on mulberry plants continues to increase along with the cutting age. Therefore, the older the plant, the higher the fiber content. Savitri et al. (2014) research results, also showed that the production of crude fiber Gliricidia (Gliricidia sepium) increases along with the cutting age.

The increasing rate in crude fiber content of the ramie plant at various cutting ages can be seen in Figure 2. It appears a pattern of escalating crude fiber content of the ramie plant formed a cubic curve. The regression equation formed is $Y=31.53-1,182 X+0,051 X^{2}$ $-0,0005 X^{3}$, the correlation coefficient $r 0.998$ indicates that the relationship between cutting age and increased crude fiber content is very strong (Sarwono, 2006).

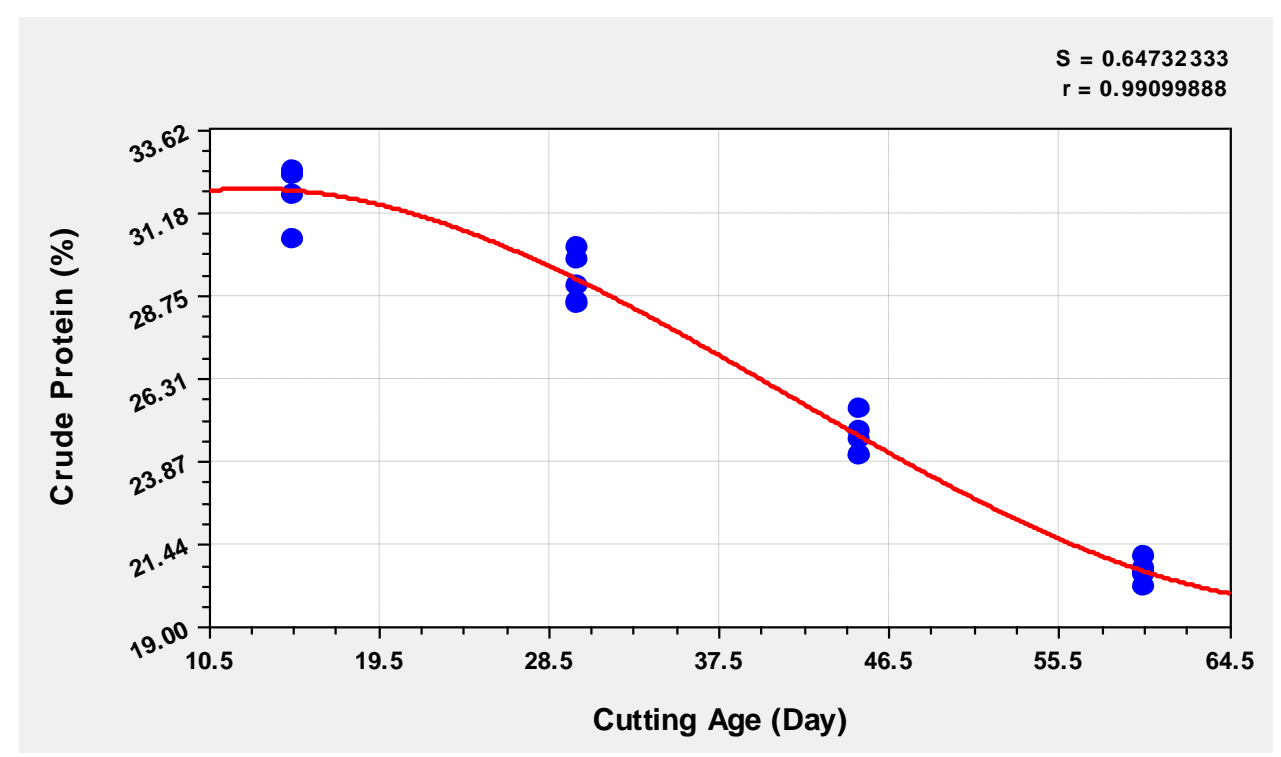

Figure 1. Crude Protein Content of Ramie Plant at Various Cutting Ages (Software CurveExpert) 
ISSN 1411-2027

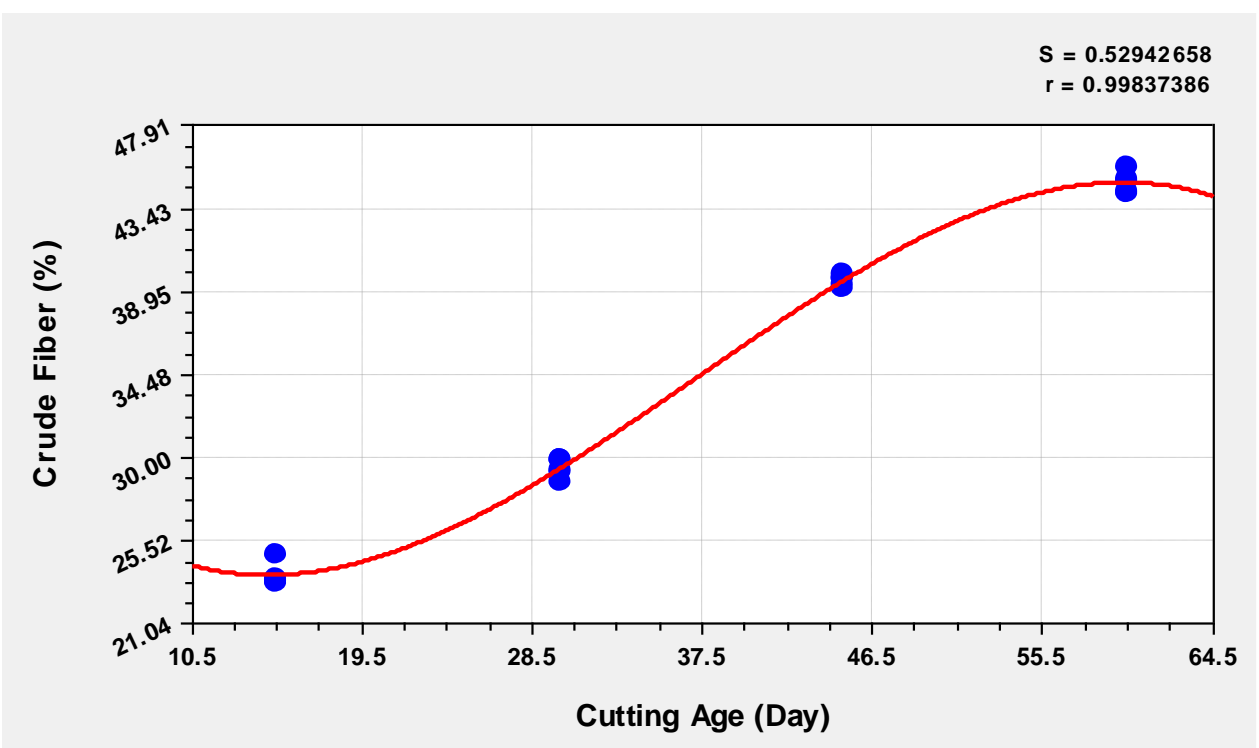

Figure 2. Crude Fiber Content of Ramie Plant at Various Cutting Age (Software CurveExpert)

\section{Lignin Content of Ramie Plant at Various Cutting Ages}

Lignin is one component of plant cell walls that cannot be digested by ruminant. The content of lignin in ruminant feed will affect the feed digestability. The data in Table 1 show that the lignin content of ramie plant increases with increasing of cutting age. The lowest of lignin content was obtained in treatment P1 or 15 days cutting age at $2.70 \%$, while the highest lignin content obtained in the treatment of cutting age P4 or 60 days at $9.88 \%$. Results of variance analysis showed that the cutting age significantly affected on lignin content of the ramie plant $(p<0.05)$. Further test with Duncan's multiple range test was conducted to determine the effect of differences between treatments.

The data in Table 1 indicate that the lignin content for each treatment show significant differences. Lignin increased proportional with the cutting age. This is because the crude fiber content continues to increase. If the crude fiber content increases proportional with the cutting age, then the lignin content which is part of the fiber fraction will also continue to increase. Moore and Jung (2001), states that the relative proportion of lignified tissues and organs typically increases as plants mature so there is often a negative relationship between digestibility and maturity.

Lignin is one of the limiting factors in forage crops that will affect the digestibility of feed. Rami harvested specifically as feed crops, it is hoped to has low lignin. Low lignin content can still be digested by cattle, while the high lignin content may decrease the digestibility because it is hard to be broken. Additionally, the cellulose, hemicellulose and lignin can also bind to the proteins in the cell walls of plants. Lignin is insoluble in rumen fluid that inhibit the action of rumen microorganisms and enzymes to digest the feed plant. This is in accordance with the opinion of Crowder and Chheda (1982), that the lignin is always bound to holocellulose (a combination of cellulose and hemicellulose) and are not significant in the very young plants age. Structurally, lignin is fenolpropane and cannot be digested by rumen microorganisms. Not only that, lignin also decreases the digestibility of other components. Therefore, forage expected to be provided to livestock at a low lignin level in order not to inhibit the action of rumen microorganisms.

Changes in lignin content in ramie plant also due to the need to provide a structure that supports the plants grow upright on land, marked by the increasing proportion of stems 


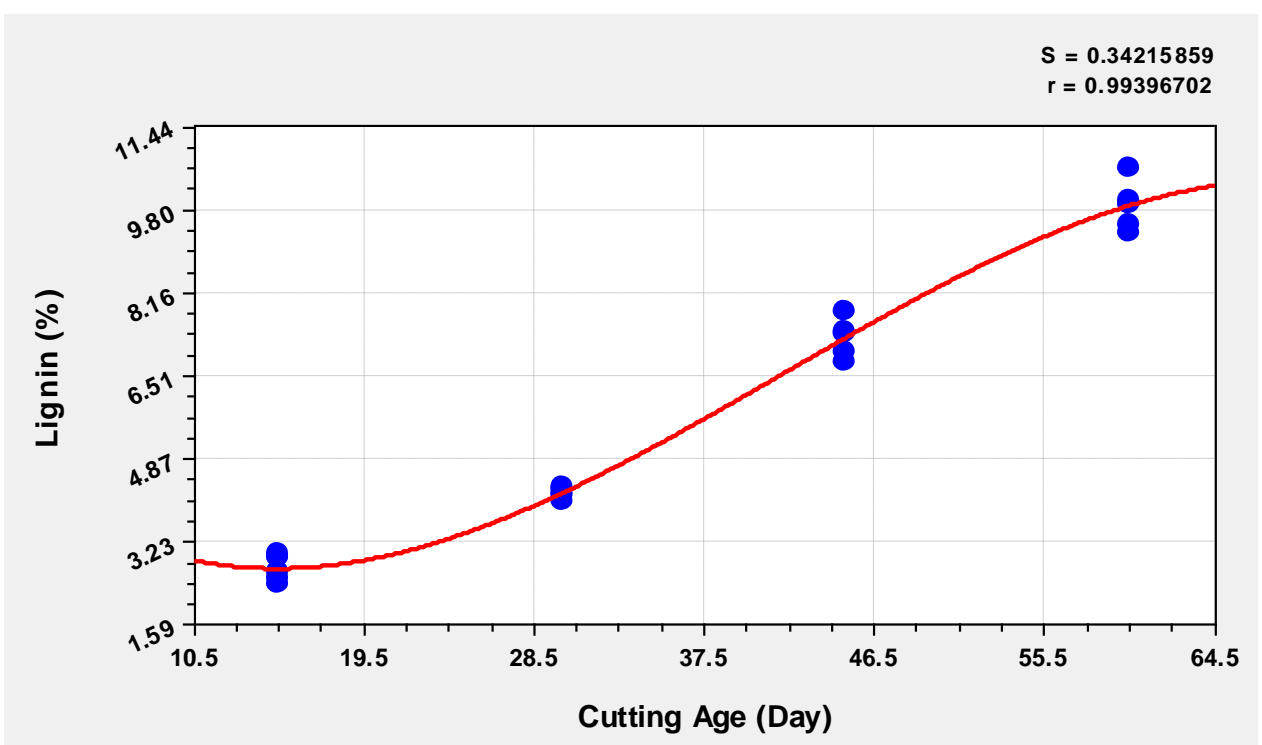

Figure 3. Lignin Content of Ramie Plant at Various Cutting Age (Software CurveExpert)

than leaves. This is in line with the opinion of Buxton and Redfearn (1997), that the rod is the part that supports the plant to erect and will have a higher lignin content than the leaves. The study results of Mansyur et al. (2007), showed that cells content of signal-grass decreased when the maturity of the plant increased, while the content of the fiber fraction (NDF, ADF, and lignin) increased.

The increasing rate in lignin content of ramie plants at various cutting ages can be seen in Figure 3. It appears a pattern of escalating lignin content of ramie plant formed a cubic curve. The regression equation formed is $Y=4,810$ $0,306 X+0,013 X^{2}-0,0001 X^{3}$, the correlation coefficient $r \quad 0.994$ indicates that the relationship between cutting age and increased lignin content of ramie plant is very strong (Sarwono, 2006).

According to Zulbadri et al. (1999), the optimal limit of lignin that can be tolerated by ruminant livestock, especially beef is $7 \%$, if it exceeds the limit it will affect the digestibility of other feed substances. Further Grabber (2005), states that high lignin content has a low level of digestibility and limits the bioconversion of forages into products from cattle.

Based on the research, the best cutting age for the ramie plant as a source of forage is at the age of 30 days. Although the age of 15 days produces high crude protein and low crude fiber and lignin, but the plant is still very young. According to Hasan (2012), some of the effects of forage which is cut too young are 1) high nutritional value, low crude fiber, 2) low productivity level, 3) palatability is high, and 4) the low ability to regrow because the carbohydrate content in the remaining is low thus providing an opportunity to weeds to grow. 30 days age is also the age of the ramie plant begins to flower, so the nutrient quality is very good.

\section{Conclusions}

Cutting age of ramie plants as forage that produces optimal nutrient quality is at the age of 30 days, with the $29 \%$ crude protein, $29 \%$ crude fiber and $4 \%$ lignin content.

\section{References}

AOAC. 2005. Officila Methods of Analysis. $13^{\text {th }}$ Ed. Association of the Official Analytical Chemist, Washington DC.

Balai Penelitian Tanaman Pemanis dan Serat. 2014. The Superior Varieties of Ramie. http://perkebunan.litbang.deptan.go.id/?p=8925 (accessed: March 14, 2014). 
Buxton DR, and DD Redfearn. 1997. Plant Limitations to Fiber Digestion and Utilization. J. Nutr. 127:814-818.

Crowder LV, and HR Chheda. 1982. Tropical Grassland Husbandry. Longman Inc, New York.

De Toledo GSP, LP daSilva, ARB deQuadros, M Retore, IG Araujo, HS Brum, P Ferreira, and R Melchior. 2008. Productive Performance of Rabbits Fed with Diets Containing Ramie (Boehmeria nivea) Hay in Substitution to Alfalfa (Medicago sativa) Hay. In: Proceeding of 9th World Rabbit Congress. Verona, Italy. June 10 13, 2008.

Despal, IG Permana, SN Safarina, and AJ Tatra. 2011. Using Various of Water Dissolved Carbohydrate Resources to Improve the Quality of Rami Leaves Silage. Media Peternakan. 34 (1): 69-76.

Djuned H, Mansyur, and HB Wijayanti. 2005. The Influence of Cutting Age on Fiber Fraction of Mulberry (Morusindica L. Var Kanva-2). In: Prosiding Seminar Nasional Teknologi Peternakan dan Veteriner. Puslitbangnak. Bogor. 859-864.

FAO. Animal Feed Resources Informaion System. 2005. Boehmeria nivea. http://www.fao.org/ag/aga/agap/frg/afris/Data/ 361.htm. (accessed: December 20, 2013).

Goering HK, and PJ Van Soest. 1970. Forage Fiber Analysis. Agric. Handbook b379, ARS, USDA, Washington DC.

Grabber JH. 2005. How Do Lignin Composition, and Crosslinking Affect Degrability? A Review of Cell Wall Model Studies. Crop Science 45:820-831.

Hasan, S. 2012. Tropical Feed Forage. IPB Press, Bogor.

Hidayat EB. 1995. Anatomy of Seed Plants. ITB, Bandung.

Mansyur, NP Indrani, T Dhalika, and AR Tarmidi. 2007. Effect of Maturity on Cell Contents, and Fiber Faction of Signal Grass (Brachiaria decumbens) that Planted under the Shade of Banana Plantations. Jurnal PROTEIN. 15: 54-59.

Margamulya Village, Cikajang District. 2005. System of Village Profile Data Collection. List of Potential Villages. Margamulya Village Cikajang District, Garut Regency, West Java Province. General of Directorate Community and Village Empowerment, Ministry of Home Affairs. Jakarta.

Moore KJ, and HJG Jung. 2001. Lignin and Fiber Digestion. J. Range Manage. 54:420-430.

Purwati RD. 2010. Strategy of Ramie Development (Boehmeria nivea Gaud). Perspective. 9 (2): 106118.

Sarwono, J. 2006. Methods of Quantitative and Qualitative Research. Graha IImu, Yogyakarta.

Savitri MV, H Sudarwati., and Hermanto. 2014. Effect of Cutting Age on Gamal Productivity (Gliricidia sepium). Jurnal Ilmu-Ilmu Peternakan. 23 (2): 2535.

Susetyo S, I Kismono, and B Soewari. 1994. Pastureland. Ranch Manager Upgrading. Directorate of Livestock Business Means. General Directorate of Livestock. Agriculture Department. Jakarta.

Wahyuni RD, and SN Kamaliyah. 2012. Study on Pattern of Tropical Alfafa Production (Medicago sativa L). Jurnal IImu-IImu Peternakan. 19 (1): 2027.

Zulbadri M, T Sugiarti, N Hidayati, and AA Karto. 1999. Opportunity of Waste Utilization of Sugar Cane Plant for Beef Fattening on Dry Land. Wartazoa. 8 (2): 33-37. 